\title{
The exploration of the whole process of College Students' education through the sense of social responsibility
}

\author{
Liying Yin \\ Jilin Agricultural University, Changchun 130118, China \\ ylyjlnd@126.com
}

\begin{abstract}
The essence of the college students' social responsibility education is to cultivate college students' social others own the sense of responsibility to the motherland, improve college students' sense of social responsibility and the rich bear spirit, able to shoulder social responsibility and times mission given by the state, is of great significance. As the ideological and political education workers, explore ways of social responsibility education responsibility. Therefore, from the perspective of the whole process of college students' education of colleges and universities, to explore ways for college students' social responsibility education in all aspects.
\end{abstract}

Keywords: College Students; Social Responsibility; the Whole Process of Education; Approach.

\section{社会责任感贯穿高校大学生教育全过程的途径探索 \\ 尹立颖 \\ （吉林农业大学 马克思主义学院, 吉林 长春. 中国130118）}

摘 要: 大学生社会责任感教育的实质是培育大学生对祖国、社会、他人、自身的责任感, 提 升大学生的社会责任意识和富有担当精神, 能够担负起国家赋予的社会责任及时代使命, 意 义重大。作为高校思想政治教育工作者, 探索社会责任感教育的途径责无旁贷。因此, 从高 校大学生教育全过程的角度, 全方位地进行大学生社会责任感教育途径的探索。

关键词：大学生；社会责任感；教育全过程；途径。

1. 前言

1989年，联合国教科文组织在《学会生存》报告中把使每个人承担起一切责任确定教育 发展的方向之一的基础上，又将 “面向21世纪的教育” 国际研讨会的主题确定为 “学会关心”, 呼吁一种道德关怀与道德责任。随之责任问题成为世界各国共同关注的问题, 社会责任感教 育也成为西方高校道德教育的主要内容。如美国的 “责任公民” 教育、英国的责任感教育、 法国的 “责任主体教育”、新加坡的全面道德教育等。由于各国社会制度不同，历史文化背 景迴异，对社会责任感教育的具体内容、方式方法也存在不同。

大学生社会责任感教育国内也一直是学界研究的热点, 而且成果颇丰, 大体有意义研究 型、现状剖析型和路径探索型三种。为我们深入研究当代大学生社会责任感教育提供了丰富 的理论素养。但是, 真正系统化、有针对性地将社会责任感贯穿到大学生教育全过程进行研 究的成果数量却很有限, 需要加大研究的力度。因此, 社会责任感贯穿高校大学生教育全过 程也是社会责任感教育途径的有益探索。 


\section{2. 社会责任感贯穿高校大学生教育全过程的途径}

2015年1月19日，中共中央办公厅、国务院办公厅印发的《关于进一步加强和改进新形势 下高校宣传思想工作的意见》中指出, “加强和改进新形势下高校宣传思想工作的主要任务, 立足学生全面发展, 努力构建全员全过程全方位育人格局, 形成教书育人、实践育人、科研 育人、管理育人、服务育人长效机制, 增强学生社会责任感、创新精神和实践能力, 全面落 实立德树人根本任务, 努力办好人民满意教育。” 因此, 大学生的社会责任感要全方位贯穿 高校大学生教育的全过程。

2. 1. 社会责任感贯穿高校大学生理论教育全过程

大学生社会责任感教育的实质是培育大学生对祖国、社会、他人、自身的责任感，提升 大学生的社会责任意识和担当精神, 能够担负起国家赋予的社会责任及时代使命。高校大学 生理论教育既包括高校思想政治理论教育, 又包括专业知识教育, 是建设富强、民主、文明、 和谐的中国特色社会主义国家的必然要求, 也是培养又 “红” 又 “专” 的、合格的社会主义 建设者的本质要求。如果大学生缺乏责任感, 即使文化知识再丰富, 也极有可能成为不符合社 会需要的 “次品”，或者是对社会没有贡献的 “废品”，甚至成为危害国家的 “危险品”。 因此, 创新高校大学生理论教育的教学模式, 将社会责任感教育融入课堂教学, 使大学生社 会责任内化于心，才能外化于行，促进大学生的社会责任感形成。

2.1. 1大学生责任感教育贯穿思想政治理论教育全过程

高校思想政治理论课是大学生思想政治教育的主阵地、主渠道, 其任务之一就是使大学 生树立对他人、对集体、对杜会、对国家的责任意识, 即社会责任感。长期以来, 大学生的 责任感教育更多是通过思想政治理论课程来实现的, 但教育效果并不理想。因此, 高校思想 政治理论教育在创新教育模式的基础上，丰富内容。

首先，以中华民族优良道德传统教育陶冶大学生的社会责任情操。五千年的历史塑造了 中华民族优良的道德传统, 内涵丰富, 是宝贵的精神财富, 是大学生思想道德建设的丰富源 泉。中国传统道德的核心是强调为社会、为民族、为国家、为人民的集体主义思想, 这其中 也包含着强烈的社会责任感的理念。在个人与社会的关系上, 强调个体对社会的价值, 如 “天 下兴亡，匹夫有责”、“先天下之忧而忧，后天下之乐而乐”、“修身、齐家、治国、平天 下” 等。这些思想对于培养当代大学生 “乐于助人”、“服务人民”、“奉献社会” 等社会 责任具有积极的作用。

其次, 以理想信念教育引领大学生的社会责任认知。中共中央、国务院《关于进一步加 强和改进大学生思想政治教育的意见》指出, “理想信念教育是大学生思想政治教育的核心”。 理想信念的缺失必然会带来社会责任感的缺乏, 树立崇高的、正确的理想信念能够使大学生 在明确社会责任认知的基础上强化责任认同, 进而激发大学生的责任意识, 最终积极履行社 会责任。所以, 社会责任感是大学生理想信念教育的应有之意, 必须引导大学生树立远大的 共同理想, 实现中华民族伟大复兴的中国梦; 同时, 还要尊重和认可大学生的个人理想, 以 激发大学生履行社会责任的积极性。只有这样, 大学生才能以先辈们为榜样, 成为新一代具 有浓厚责任感的社会主义建设者。

再次, 以马克思主义理论教育奠定大学生的社会责任基石。马克思主义理论作为全人类 的思想宝库, 博大精深, 给人以启迪。如, “人与社会关系” 理论体现了人与社会发展的统 一、价值的统一, 是大学生树立正确的责任意识的基本前提; 马克思主义具有与时俱进的理 论品质, 中国化的马克思主义是马克思主义基本原理同中国实际相结合的产物, 是中国特色 社会主义共同理想的理论基础。要实现中国特色社会主义共同理想, 就要坚持 “富强、民主、 文明、和谐、自由、平等、公正、法治、爱国、敬业、诚信、友善” 的社会主义核心价值体 系。这也是大学生树立正确的责任意识的方向性指导。只有这样, 将大学生个体多样化的价 值诉求统一于社会主义核心价值体系中, 才能把个人的理想与国家的命运紧密地联系在一起, 为实现中国特色社会主义共同理想做出贡献。 


\subsection{2社会责任感贯穿高校大学生专业理论教育全过程}

高校思想政治理论课虽然具有其他课程不可比拟的优势，但并不是唯一的阵地和渠道， 还要把社会责任感教育蕴含在各门专业课中。一方面, 各门专业课的知识内容也蕴含着丰富 的人文知识, 都是科学家们不断追求真理、为了人类的幸福而不计个人得失, 承担起社会责 任的结果。因此, 在各门专业课教学过程中要充分挖掘教学内容背后的道德责任感, 各个学 科要共同承担培养学生责任感的任务; 另一方面, 一种正确的责任意识还必须要具备扎实的 践行社会责任的能力。因此, 各门专业课教学过程中要培养大学生具备相应的专业知识和科 技创新能力, 为走出校园投身中国特色社会主义伟大实践做出自己应有的贡献奠定坚实的基 础。

此外, 社会责任感教育还要融入入学教育、军事训练和就业教育的各个环节中，引导 大学生养成对自己负责、对他人负责以及对社会负责的道德自觉。

2. 2. 社会责任感贯穿高校大学生社会实践全过程

一个人的责任感是知、情、行过程的统一, 而统一的基础就是社会实践。责任感的培养 需要知识理论的灌输, 需要环境的熏陶, 更要从实践检验中确立。宋代诗人陆游曾经写过 “纸 上得来终觉浅, 绝知此事要躬行” 的诗句。因此, 要在强化社会责任意识的同时, 认识到人 生的真正价值在于对社会的奉献。一方面, 在各门课程的实践教学中引导学生进入 “社会角 色”，感同身受，激发责任热情; 另一方面，鼓励大学生走出校园，参加社会公益活动、社 区敬老爱幼活动，志愿者活动、“三支一扶” 活动、勤工助学活动等等，既了解社会，了解 国情, 又在活动中学以致用, 体验到愉快的成就感, 社会责任就会内化为大学生思想的一部 分，从而牢固地树立起国家主人翁责任感。此外，加大社会责任教育实践活动经费的投入， 加强实践育人基地建设。建设红色教育基地, 使大学生 “身临其境” 地感受到前辈的奉献精 神, 强化了对他人、对集体、对杜会、对国家的责任意识; 建设学科教育基地, 鼓励大学生 用己所学贡献社会, 增长了才干，体现了价值，从而获得自我肯定与社会肯定，强化了责任 感，保证了育人效果。

2. 3. 社会责任感贯穿高校大学生校园文化建设全过程

《三字经》云：“昔孟母，择邻处”，说的是教育环境对人的影响至关重要。校园文化 是大学生群体的需求在文化上的真实反映, 最贴近学生的生活实际, 对大学生最具感召力。 校园文化是对大学生进行社会责任感教育的重要方式。积极开展丰富多彩、健康向上的校园 文化活动，如，科技、文艺、体育、娱乐、道德模范和先进事迹报告会等活动，使大学生在 校园文化熏陶中形成强烈的社会责任感; 充分利用校园广播、校园网络、校园梪窗、校园 环境等载体，如，修建具有高度社会责任感的名人雕像、把富有社会责任感的校训和优良传 统映刻在学校建筑上等, 营造浓郁的校园社会责任感文化氛围, 在潜移默化中推进社会责任 感的教育。

2.4. 社会责任感贯穿高校大学生日常教育管理全过程

大学生社会责任感教育, 与高校的管理制度和管理工作关系密切。要帮助大学生形成强 烈的社会责任感，就必须使管理制度和管理过程体现责任意识，以影响和感染大学生。高校 管理部门要坚持以 “以学生为本” 进行学生管理工作。首先, 高校要制定科学、合理的学生 管理制度，使学生在遵守管理制度的过程中知晓作为学生应有的责任和义务，以此来强化大 学生自身责任意识; 其次, 加强教学管理。高校应适当调整平时表现在总成绩中的比重, 以 此来督促大学生自身修养, 在努力的过程中学会对自己负责, 从而加强其社会责任感; 再次, 高校必须加强大学生生活管理, 培养他们良好作息习惯, “节粮、节水、节电”，对自己负 责, 对生活负责, 大学生才能真正做到对社会负责。此外, 通过品学兼优、富于社会责任感 的学长来引导低年级学生, 发挥学长榜样的作用, 以此增强其社会责任感。

2.5. 社会责任感贯穿高校师德建设全过程

“学高为师, 德高为范”。在大学生社会责任感的教育中, 加强教育工作者的榜样示范作 用。培养一批具有良好素质、健康人格和个人鬼力的工作者, 给予大学生正确的指引和有效 
的帮助, 促进大学生社会责任感的培养。首先, 教师必须得自身具备强烈的社会责任意识, 有爱心, 有责任心, 率先垂范, 兢兢业业做好教学工作, 用自己高度的责任感去感染和培养 学生, 提高大学生高度的社会责任感。其次, 建立健全高校教师任职资格准入制度, 把好教 师队伍入口关。认真落实高校教师职业道德规范要求。加强师德考核, 把师德表现作为教师 职称评聘、职务晋升、年终奖励的首要依据。实行师德一票否决制, 从制度上形成师德师风 建设的长效机制。再次, 抓好一线教师、专兼职辅导员、学生管理干部队伍建设。学校在赋 予他们工作任务的同时, 也要关心他们的工作、学习和生活, 解决他们的后顾之忧, 使他们 在日常工作中以高尚的师德和良好的师风教育和影响学生, 引导大学生树立正确的世界观、 人生观和价值观, 增强大学生的社会责任感。

\section{3. 结论}

大学生要承担起中华民族伟大复兴的历史重任, 必须具有强烈的社会责任感。高校作为 社会责任感教育的主阵地, 对大学生的社会责任感教育是一项长期的系统工程, 离不开学校 的教育、管理和引导, 要把理论教育与实践教育合理结合, 充分发挥教师的榜样作用, 校园 文化环境的重陶作用。我们相信, 通过高校全体教职工的共同努力, 大学生必将以强烈的社 会责任感承担起自己的历史使命, 必将在实现中国梦的征程上发光发热。

\section{致谢}

本文是2016年度吉林省教育科学 “十三五” 规划课题 “社会责任感贯穿高校大学生教育 的全过程研究”（编号GH16201）的阶段成果。

\section{References}

[1]. Information on: http://education.news.cn/2015-01/19/c_1114051345.htm.

[2]. Ke Wen, The existing problems and countermeasures of the contemporary college students' social responsibility, MASTER, Central China Normal University, CHINA, 2013.p.21-22 